\title{
Religião, ciência ou auto-ajuda? Trajetos do Espiritismo no Brasil ${ }^{1}$
}

\author{
Sandra Jacqueline Stoll \\ Professora do D epartamento de A ntropologia - UFPR
}

RESUMO : O objetivo deste artigo éapresentar certas configurações recentes do Espiritismo no Brasil. Tomando como ponto de partida a bibliografia produzida sobre o tema, chama-se atenção, em primeiro lugar, para a omissão desta quanto às relações estabelecidas entre o Espiritismo e o Catolicismo; em seguida, deslocando o foco para a situação contemporânea, analisa-se as novas interlocuções que vêm sendo estabelecidas pelo Espiritismo como estratégia de inovação da doutrina. Baseada em estudos de caso, essa discussão se constitui em torno de três personagens - Chico Xavier, Waldo Vieira e Luiz Antonio Gasparetto - , os quais sintetizam, por meio de seus percursos pessoais, formas diversas de expressão e/ ou contestação da "tradição" espírita.

PALAVRAS-CHAVE: Espiritismo, santidade, Chico Xavier, Waldo Vieira, Luiz Gasparetto.

\section{Chico Xavier: a procissão do adeus}

D esde as primeiras horas eram imensas as filas no velório de Chico Xavier, médium cuja trajetória de vida se confunde com a história do Espiritismo no Brasil. O local escolhido foi a Casa da Prece, o centro espírita de Uberaba, no Triângulo Mineiro, onde Chico X avier recebeu, nos últimos quarenta anos, romeiros de todas as partes do país. Foram dois dias de despedida, nos quais compareceram, segundo se calcula, cerca de 100 mil pessoas. A fila à frente da casa tinha três quilômetros; 
SAndra Jacqueline Stoll. Religião, CiÊnCia ou aUto-ajuda?

a espera era de quase três horas. Por hora passaram, aproximadamente, 2.500 pessoas. 0 cortejo até o cemitério São João Batista, conduzido por bombeiros, foi acompanhado por mais de 30 mil pessoas. Entidades assistenciais, artistas, políticos e empresários enviaram mais de 150 coroas de flores. Lideranças de segmentos diversos do campo religioso também lhe renderam homenagem ${ }^{2}$.

Chico Xavier faleceu aos 92 anos, de uma parada cardíaca, em sua casa. Era 0 dia 30 de junho de 2002, data da quinta conquista do Brasil numa Copa do Mundo. Segundo relatos de familiares, Chico Xavier levantara cedo nesse dia como de costume. Não assistiu ao jogo, mas quis saber o resultado. Mais tarde percorreu cada ambiente de sua casa e também visitou as salas da Casa da Prece. Recolheu-se imediatamente após o jantar, vindo a morrer logo em seguida.

Essa forma silenciosa, serena e sem alarde de transição para o "outro lado da vida", como dizem os espíritas, parece condizente com um dos atributos mais lembrados de Chico X avier: a humildade.

Nem sempre, porém, foi essa a aura em torno de sua imagem. Especialmente no início da carreira, sua presença na mídia esteve freqüentemente associada a eventos polêmicos. Os primeiros registros, realizados pela imprensa, datam dos anos 30, época em que o jornal 0 Globo, do Rio de Janeiro, realizou um inquérito sobre suas atividades. 0 mote dessa investigação foi o lançamento de seu primeiro livro, Parnaso de além-túmulo, obra em que apresenta poesias póstumas de autores "ilustres": Casemiro de Abreu, O lavo Bilac, Augusto dos Anjos, etc ${ }^{3}$. Largamente debatida na ocasião, a credibilidade desse tipo de produção literária mobilizou os círculos intelectuais da época. Uma década mais tarde o tema voltou à baila com a notícia de que uma ação judicial havia sido movida pela família Humberto de Campos contra o médium Chico Xavier e a Federação Espírita Brasileira. Nesse segundo inquérito jornalístico, além da participação de críticos literários e jornalistas, contou-se também com o envolvimento de juristas, uma vez que a questão em pauta era o destino legal dos direitos autorais em se tratando de produção literária post mortem4. 
Revista de Antro pologia, São Paulo, USP, 2002, v. 45 nํำ.

Mesmo depois de ter sua autoridade reconhecida, as polêmicas continuaram. Em 1979, por exemplo, Chico Xavier voltou a ter seu nome envolvido em debates jurídicos, desta vez em decorrência da inclusão de duas mensagens suas, psicografadas, nos autos de defesa em dois processos de crime. Alardeado pela imprensa espírita, esse fato teve repercussão inclusive no exterior ${ }^{5}$. Isso sem contar inúmeras outras matérias jornalísticas produzidas nesse ínterim motivadas por boatos sobre sua vida pessoal, como supostos namoros, casamentos, a discussão sobre sua sexualidade, etc.

Os anos 80 constituem o turning point de sua imagem na mídia: o lançamento da campanha de sua candidatura ao prêmio Nobel estendeu para além do campo espírita e em âmbito internacional a imagem de Chico Xavier como "homem santo" ${ }^{6}$. O s programas de televisão de que participou contribuíram para essa construção. Sua estréia neste veículo de comunicação deu-se nos anos 70, quando participou do então famoso Pinga-fogo. Além de responder a perguntas de jornalistas, do público e de representantes de diferentes instituições religiosas, neste programa Chico Xavier realizou, a pedidos, o que se considera ter sido a primeira sessão mediúnica televisionada7. A repercussão de público alcançada por esse programa estimulou, em anos posteriores, a realização de outras entrevistas, bem como a produção de vários documentários.

No entanto, essa projeção social do médium teve pouca repercussão no meio acadêmico. Luiz Eduardo Soares chama atenção para esse fato num artigo publicado em 1979. D uas décadas decorreram, porém, antes que o Espiritismo se tornasse objeto renovado de interesse nas Ciências Sociais ${ }^{8}$ e que Chico X avier viesse a ocupar o devido lugar no universo dos estudos sobre a religiosidade brasileira.

0 presente trabalho se inscreve entre os primeiros a fazerem de sua vida e obra tema central de reflexão, trazendo à tona o papel que Chico $\mathrm{X}$ avier desempenhou no delineamento do éthos católico de que se revestiu a doutrina espírita no Brasil. 
O utra lacuna na produção recente sobre 0 tema diz respeito à reflexão sobre as novas formas de presença e inserção do Espiritismo no campo religioso brasileiro. Como assinalam Brandão (1988) e Giumbelli (1997), dentre as religiões ditas brasileiras, o Espiritismo tem sido a menos estudada. O bservação válida, inclusive, para os artigos recentes que tratam da dinâmica contemporânea do campo religioso na sociedade brasileira: nestes são freqüentes as análises sobre as mudanças que vêm ocorrendo no meio católico, no contexto das tradições afro e no âmbito pentecostal. Raramente, porém, esses textos se referem ao universo espírita?

Reverter essa tendência implica um trabalho de mais fôlego. Na tentativa de contribuir para a discussão, o presente artigo se desdobra em duas partes: na primeira realizo uma revisão da literatura produzida sobre 0 Espiritismo. A análise da história de vida e carreira religiosa de Chico Xavier segue como ilustração, sugerindo, com base na estratégia biográfica, como se deu a construção do "estilo católico" de que se revestiu o Espiritismo no Brasil. Na segunda parte desloco o olhar, focalizando dois outros personagens, originários do campo espírita, cujos percursos pessoais apontam para duas das tendências contemporâneas de inovação da doutrina: uma que envereda na direção do cientificismo, outra que investe na carnavalização como forma de produção de inovações. Apresentados como tipos-ideais esses três personagens apresentam uma grande riqueza no que diz respeito à particularização de certas possibilidades, ao passo que em conjunto permitem perceber processos mais abrangentes da dinâmica contemporânea no campo religioso.

\section{Entre a França e o Brasil: a invenção de tradições}

Allan Kardec ainda escrevia os principais tomos de sua obra, quando o Espiritismo aportou ao Brasil, sendo, portanto, divulgado quase simultaneamente à sua difusão na Europa ${ }^{10}$. Os estudos sociológicos aqui realizados sobre o tema, no entanto, são relativamente recentes. D ois 
Revista de Antropologia, São Paulo, USP, 2002, v. 45 noㅡ.

autores, Cândido Procópio Camargo ${ }^{11}$ e Roger Bastide ${ }^{12}$, assinam os primeiros trabalhos, introduzindo a questão que nortearia boa parte da discussão dos estudos de religião nos anos 60 e 70: como explicar a difusão de religiões populares, especialmente o Pentecostalismo, 0 Espiritismo e as religiões afro-brasileiras, num contexto de aceleração do processo de urbanização? O u em outros termos: como explicar a proliferação da religiosidade popular, tida como símbolo de "atraso", justamente no pólo do desenvolvimento urbano e econômico do país, ou seja, no espaço social e simbólico tido como emblemático da "modernidade"?

Inaugurando a discussão desse tema, esses autores se tornaram referência de toda a produção subseqüente ${ }^{13}$. D entre as idéias que postulam, tornaram corrente a assertiva de que o Espiritismo sofreu uma significativa mudança no processo de sua transplantação para o Brasil, considerando-se que na França, onde teve origem, prevalecia a ênfase na dimensão experimental e científica da doutrina, enquanto no Brasil tornou-se dominante a feição mística, religiosa.

Cândido Procópio Camargo sustenta essa idéia já às primeiras páginas do seu livro Kardecismo e U mbanda. Neste afirma: "A ênfase no aspecto religioso da obra de Kardec constitui [...] o traço distintivo do Espiritismo brasileiro e, talvez, seja a causa de seu sucesso entre nós" (1961: 4). Afirmação que reitera adiante, quando declara:

Tanto a doutrina, como especialmente a prática espírita, ganharam no Brasil novo alento, desenvolvendo conotayoes e ênfases especiais que as adaptaram à realidade brasileira. A história dessa adaptação é um aspecto [...] da constituição de uma religião original entre nós. (: 8; destaques meus)

Alguns anos mais tarde Procópio Camargo reapresenta essa idéia em seu novo livro, Católioos, espíritas e protestantes (1963). Nesta obra o autor sugere que a doutrina kardecista "não sofreu modificações essenciais quando transplantada para a sociedade brasileira, embora a adaptação a uma situação social nova tenha gerado algumas características especiais" (: 162; destaques meus). D entre estas últimas destaca o fato de que "no Brasil 0 aspecto religioso torna-se preponderante, em contraposição ao filosófico e 
Sandra Jacqueline Stoll. Religião, ciênCia ou auto-ajuda?

científico" (idem; destaques meus). 0 autor atribui essa mudança de ênfase doutrinária à "tradição cultural brasileira", caracterizada como "impregnada de um estilo sacral de compreender a realidade" (1961: 112). D onde conclui que esta é uma sociedade "moderna", porém, contraditória: "embora a cultura brasileira seja naturalmente complexa" e, portanto, oriente-se "também por valores estritamente racionais e profanos, cremos não ser exagerado afirmar que a solução sacral para a vida assume, entre nós, importância considerável" (idem; destaque meu).

Roger Bastide partilha dessa idéia, mas envereda a análise noutra direção. Ele sugere que o Espiritismo sofreu interpretações diversas na sociedade brasileira, segundo a classe social. Segundo ele, os segmentos de classe alta, "intelectualizados", tendem a enfatizar as experiências de tipo científico. Já o Espiritismo praticado nos centros, que concentra os segmentos de classe média, caracteriza-se por um cunho acentuadamente religioso. Mas a ênfase de suas práticas é terapêutica, tal como se observa entre os segmentos populares. Com relação a estes últimos, porém, ressalva: "Aqui [...] o caráter médico do espiritismo continua, tanto mais que a tradição do curador, da magia curativa, de definição da doença pela ação mística de feiticeiros ou da vingança dos mortos, permanece a base da mentalidade primitiva" (1985[1960]: 433).

A ênfase no aspecto terapêutico, associado a noções mágicas, constitui, portanto, o diferencial do Espiritismo brasileiro. Mas embora Bastide sinalize cortes raciais e/ ou de classe na interpretação da doutrina espírita, conclui generalizando: "Em suma, o espiritismo foi transformado pelo meio brasileiro, meio [este] mais confiante no 'curandeiro' que no médico e que não separa o sobrenatural da natureza" (idem).

Divergentes, as duas linhas de interpretação angariaram inúmeros seguidores. Não cabe aqui, porém, reconstruir genealogias. Importa sinalizar que a perspectiva comparativa, relacional, que inaugura a análise do fenômeno, tornou-se o modo corrente pelo qual passou a se pensar a história do Espiritismo no Brasil. 
D entre as imagens resultantes interessa-me retomar uma que se tornou corrente, dentro e fora dos meios acadêmicos. Refiro-me ao suposto, com base nas análises acima, de que no Brasil a doutrina kardecista sofreu uma distorção. Autores nacionais bem como estrangeiros partilham dessa posição. Revisões recentes de processos de confronto cultural permitem, no entanto, recolocar a questão em outros termos. O u seja, considerar deslocamentos de ênfases doutrinárias como distorcão ou adulteração de um modelo original obscurece 0 fato de que toda versão, toda reinterpretação é sempre um ato criativo. Sahlins, em seu livro Ilhas de história, chama atenção para essa questão ao afirmar que a ordem cultural não é estática, mas alterada na ação, isto é, sujeita a riscos empíricos. Isso porque

agindo a partir de perspectivas diferentes e com poderes sociais diversos para a objetivação de suas interpretações, as pessoas chegam a diferentes conclusões e as sociedades elaboram os consensos, cada qual à sua maneira. A comunicação social é [portanto] um risco [...]. E os efeitos desses risoos podem ser inovayoues radicais. (1990: 10; destaque meu)

Tratar a experiência do confronto cultural, mais especificamente a diversidade de respostas locais ao sistema mundial dessa perspectiva, fornece uma pista para se pensar as especificidades assumidas pelo Espiritismo no Brasil a partir de um novo enfoque. O u seja, argumentando com Sahlins, é possível afirmar que privilegiar determinadas práticas assim como deslocar a ênfase de certos preceitos doutrinários envolvem um ato criativo. Trata-se de reinterpretação, isto é, de uma particularização cultural e histórica de idéias e práticas concebidas com pretensão de universalidade. Nesse sentido, o E spiritismo à brasileira seria uma versão original e não um produto menor, adulterado ou desviante.

Resta saber como se construiu essa originalidade. 


\section{Construindo laços, definindo fronteiras: Espinitismo, Catolicismo e as religiões afro}

A literatura mencionada tende a situar o Espiritismo no campo religioso brasileiro a partir da interlocução por este estabelecida com as religiões de tradição afro. Essa perspectiva de análise engendrou duas posturas distintas: 1) de um lado, há autores que pensam as relações entre o Espiritismo e as religiões de tradição afro em termos de um continuum - isto é, como variação empírica de um mesmo princípio de estruturação cosmológica e de produção da experiência religiosa (Camargo,1963 e 1973; Birman, 1995); 2) outros concebem o Espiritismo por oposição às religiões afro-brasileiras, uma espécie de espelho invertido, seja quanto às suas características sociais e étnicas, seja quanto à estrutura ritual e doutrinária (Maggie, 1992; Ortiz, 1991 [1978]; dentre outros).

Esses enfoques que fazem dos cultos de possessão uma unidade, pelo princípio da afinidade ou pelo princípio da oposição são, sem dúvida, pertinentes. No entanto, tal recorte tende a omitir ou, pelo menos, a relegar a um segundo plano as relações estabelecidas entre o Espiritismo e o Catolicismo, religião ainda hegemônica no país. É o que se verifica, por exemplo, no estudo de Maria Laura Cavalcanti (1983), para quem a questão sequer se coloca. Outros autores se referem ao tema sem problematizá-lo, como Renato Ortiz, para quem as relações entre Espiritismo e Catolicismo são tidas como dadas: "Consideramos a influência do catolicismo como sendo implícita", diz ele (1991 [1978] : 34). Cândido Procópio Camargo também partilha dessa posição: “[...] no kardecismo predomina a formulação ética de inspiração cristã" (1963), diz ele, sem se preocupar em qualificar o modo como esta foi apropriada e/ ou reinterpretada pelo Espiritismo.

Uma das lacunas da produção sobre o tema consiste justamente no fato de não se questionar como 0 imaginário e as práticas católicas impactaram 0 E spiritismo, influenciando de forma significativa o modo de sua expressão no Brasil. Aubrée e Laplantine (1990) fazem menção a essa 
Revista de Antropologia, São Paulo, USP, 2002, v. 45 nํำ.

questão ao sugerirem que o modo como os brasileiros se relacionam com os espíritos não faz mais que "prolongar, ampliar e sistematizar o que se poderia chamar de cultura brasileira dos espíritos" (: 85), cujo principal traço seria a "intimidade com os santos, eguns e orixás" (idem). Mas também esses autores não avançam a discussão e acabam realçando, como os demais, as relações entre o Espiritismo e as religiões de tradição afro.

0 que se perde de vista nessas análises é a complexidade das relações estabelecidas pelo Espiritismo no campo religioso brasileiro, em particular aquelas que dizem respeito às disputas e negociações realizadas com a religião dominante, hegemônica no país ${ }^{14}$. Privilegio essa relação uma vez que considero, em oposição à tradição consolidada na literatura, que o Espiritismo definiu sua identidade elegendo como sinais diacríticos elementos do universo católico. Isso significa afirmar que sua relação com a religião dominante no país não se resumiu simplesmente ao endosso de certas idéias ou práticas rituais, como sugerem autores acima mencionados. 0 "matiz perceptivelmente católico" do Espiritismo brasileiro decorre, conforme pretendo demonstrar, da incorporação de um dos substratos fundamentais da cultura religiosa ocidental: a noção cristã de santidade.

Chico X avier configura nesse contexto, como pretendemos demonstrar adiante, um paradigma dessa construção. No cenário contemporâneo, porém, é possível, vislumbrar novas tendências. Mas estas reforçam 0 argumento acima, uma vez que é em larga medida contra esse "viés católico" de que se revestiu o Espiritismo brasileiro que começaram a emergir, a partir dos anos 80, novas tendências de filiação nesse campo.

0 presente artigo ilustra essas diferentes versões que hoje convivem no campo espírita a partir da análise da trajetória de três personagens: 1) Chico Xavier, o primeiro deles, ilustra a construção da "tradição" espírita brasileira, cuja marca consiste na síntese com o Catolicismo; 2) Luiz Antonio Gasparetto e 3) Waldo Vieira sintetizam, cada um à sua maneira, tendências da crítica contemporânea a esse modelo que se tornou hegemônico, o primeiro realizando-a por meio da busca de 
diálogo com temas e práticas do chamado neo-esoterismo $0^{15} \mathrm{e}$ do universo da auto-ajuda, enquanto o segundo enveredou em busca de uma nova síntese com a ciência.

Apresento-os aqui em contraponto, a partir da construção narrativa de suas biografias, sem ter a intenção de contextualizar historicamente suas trajetórias pessoais. Clifford G eertz já advertia, em 0 bservando el Islam, que "observar a história a partir de personalidades, especialmente personalidades dramáticas, é sempre perigoso"(1994 [1968]: 97). 0 risco do empreendimento, porém, justifica-se, diz ele, quando se trata de personagens cujas carreiras sintetizam um determinado período da história de seus países. Entendendo ser este 0 caso, decidi assumir 0 risco.

\section{O Espiritismo segundo Chico Xavier}

Personagem paradigmática do Espiritismo brasileiro, Chico Xavier é aqui considerado um dos principais responsáveis pela consolidação da "feição católica" de que se revestiu o Espiritismo no Brasil ${ }^{16}$. Essa síntese foi por ele produzida pela introdução tanto de práticas populares como institucionais do Catolicismo na performance espírita. Síntese que Chico Xavier realiza, na sua biografia, por duas vias: por um lado, a relação santorial, que caracteriza o Catolicismo popular, serviu-lhe de modelo para a construção e narrativa de sua experiência com os espíritos; por outro, sua imagem pública - 0 ideal de santidade que conforma o seu estilo de vida -, inspira-se em princípios da prática monástica católica. É o que pretendo demonstrar revendo alguns aspectos de sua biografia.

\section{Uma vida contada a muitas mãos}

Autor de mais de 400 títulos espíitas, Chico Xavier pouco escreveu sobre si mesmo. D ois prefácios, escritos nos anos 30, foram os únicos documentos encontrados ${ }^{17}$. Há, porém, inúmeras biografias produzidas ao longo de sua carreira que compilam casos, episódios e eventos contados, em primeira 
Revista de Antropologia, São Paulo, USP, 2002, v. 45 nํำ.

mão, pelo próprio Chico Xavier. Assim, por meio de terceiros a sua narrativa foi transformada numa espécie de "história oficial" ${ }^{18}$.

Uma das características desse relato é que ele se constrói em torno de uma única chave: a do sofrimento. Essa categoria narrativa estabelece laços de continuidade entre as etapas fundamentais de sua carreira e trajetória pessoal, cuja estrutura reproduz o modelo hagiográfico: 1) a fase profana, período que engloba a sua infância e adolescência, é marcada por conflitos surgidos no âmbito familiar e das relações primárias. Nessa etapa o modo de interpretação da experiência mediúnica é característico: tal como na história de vida de outros médiuns, esta é uma ex periência rejeitada; 2) a conversão ao Espiritismo marca o início de uma nova etapa, de liminaridade, em que o afastamento do mundo é sinalizado pela tensão entre projetos pessoais e a imposição de um rígido programa de disciplinamento moral e de manejo dos "dons"; 3) a consolidação de sua liderança no campo espírita, associada à produção literária intensa, marca simbolicamente 0 itinerário de retorn $0^{19}$. Nessa etapa, assumindo a vida como cumprimento de uma missão, a renúncia a projetos de caráter pessoal se consolida fazendo-se acompanhar da produção de um estilo de vida exemplar.

Nesse percurso o confronto inicial com o imaginário católico e, posteriormente, a reinterpretação e apropriação de idéias e práticas deste constituem uma marca fundamental. Esse processo não envolve, porém, apenas a incorporação de práticas do Catolicismo popular, mas também do Catolicismo institucional, eclesiástico, o que se torna sobretudo relevante na terceira etapa de sua trajetória como se verá adiante.

\section{"Com o diabo no corpo": a interpretação católica do fenômeno mediúnico}

Nascido a 2 de abril de 1910, em Pedro Leopoldo, Minas Gerais, Chico Xavier teve uma educação eminentemente católica como era corrente entre os moradores do lugar. Mas já na infância, segundo 
SAndra JacQueline Stoll. Religião, ciênCia ou AUto-AJuda?

seus relatos, começaram a ocorrer as primeiras manifestações de "contato com os espíritos".

O evento propulsor foi a morte de sua mãe, fato ocorrido em 1915, quando ele tinha apenas cinco anos. João Cândido, seu pai, era vendedor de bilhetes de loteria e viajava muito. Vendo-se, portanto, sem condições de criar os filhos sozinho resolveu distribuí-los entre parentes e vizinhos. Chico Xavier foi entregue à Rita de Cássia, sua madrinha, mais tarde sarcasticamente por ele definida como "grande educadora". D e acordo com seus relatos ela o surrava com vara de marmelo todos os dias. Muitas vezes sem motivo. Os castigos, porém, aumentaram depois que ele contou-lhe "ter visto e conversado com a mãe no fundo do quintal". A partir daí, além da surras, a madrinha passou a darlhe garfadas na barriga acusando-0, em função de suas "conversas com os mortos", de "ter parte com o diabo". Esse suplício durou dois anos.

D epois disso Chico voltou a morar com o pai, que se casara novamente. A reestruturação da vida familiar não interrompeu, porém, a ocorrência das "visões". Segundo se conta, freqüentemente ele "levantava no meio da noite, batia papo com fantasmas e muitas vezes estragava 0 café da manhã do pai com notícias de parentes mortos e descrições de viagens por cenários fantásticos" (Souto Maior, 1995: 16). Essas experiências ele também relatava, em confissão, ao padre Scarzelli, pároco da cidade.

Sua madrasta, Cidália, com quem ele conversava nos fins de tarde ao pé do tanque, por inúmeras vezes ouviu-o dizer que "via próximas ao varal figuras cobertas com mantos coloridos" (: 17). Ela, segundo se conta, dava-lhe crédito, ao contrário de dona Rosária, sua professora primária. Ao participar de um concurso de redação instituído pelo governo do Estado de Minas G erais em comemoração ao primeiro centenário da Independência, Chico levantou-se em meio à prova para comunicar à professora que pressentia a presença de um homem que lhe ditava um texto. Sem dar-lhe muita atenção, ela pediu que ele voltasse ao seu lugar e terminasse a prova. A notícia, porém, espa- 
Revista de Antropologia, São Paulo, USP, 2002, v. 45 nํำ.

lhou-se na sala e na aula seguinte os colegas fizeram-lhe um desafio. Como prova queriam que o "tal homem" viesse "outra vez, ali mesmo [...] à frente de todos para escrever sobre um tema escolhido por eles". O tema proposto, escolhido ao acaso por um dos meninos foi o grão de areia. Chico relata: "lembro-me que o espírito [...] ao meu lado começou ditando: 'Meus filhos, que ninguém escarneça da criação. O grão de areia é quase nada, mas parece uma estrela"' (Barbosa, 1992 [1967]: 17).

Fatos como esses se repetiam quase diariamente, em sonhos, na escola, nos momentos de ócio. João Cândido, pai de Chico Xavier, inúmeras vezes ameaçou internar o filho num sanatório. A tese de que se tratava de caso de loucura era, porém, refutada pelo padre Scarzelli, que procurava aplacar a situação com o receituário católico tradicional: novenas, penitências, rezar mil ave-marias...

Essas duas posições com relação ao fenômeno mediúnico (assinaladas, de um lado, pelo padre e a madrinha nos termos da religião, de outro, pelo pai, que aderia ao argumento médico) ilustram os termos do debate da questão na época. Conforme Giumbelli (1997), que se dedica ao estudo desse tema, as primeiras décadas do século XX constituem o período em que o pensamento médico no Brasil amplia significativamente 0 espaço editorial conferido ao tema, o que se observa pelo aumento do número de artigos, teses elivros sobre o assunto (: 198). Construindo-se à época como discurso hegemônico, a perspectiva médica teve 0 endosso do discurso jurídico, resultando dessa aliança um prolongado embate com a versão tradicional, religiosa do fenômeno (Giumbelli, 1994).

Mas numa pequena cidade do interior de Minas Gerais, como era Pedro Leopoldo no início do século XX, o padre era ainda considerado uma "autoridade". Ou seja, a ascendência do padre sobre as famílias dos meios populares corria incontestada. $\mathrm{O}$ relato biográfico de Chico X avier é exemplar nesse sentido. Vários são os episódios relembrados que sugerem o poder da opinião padre. Chico Xavier lembra, 
SAndra Jacqueline Stoll. Religião, CiÊnCia ou aUto-ajuda?

por exemplo, que por ordem do pároco participou, aos nove anos, de uma procissão carregando uma pedra de 15 quilos na cabeça. A penitência devia ser complementada pela obrigação de repetir mil vezes a ave-maria. Não se tratava, porém, de prática isolada. Impuseram-lhe que freqüentasse regularmente a igreja, participando inclusive das novenas. O s resultados, contudo, não foram os esperados. Segundo seu relato, enquanto rezava e contava acompanhando a procissão, "um espírito desocupado fazia caretas e bocas para atrapalhar seus cálculos" (Souto Maior, 1994: 11). Além disso, quando estava na igreja, cumprindo as novenas, "assombrações flutuavam sobre os bancos e beijavam os santos" (idem). Padre Scarzelli decidiu então "ser mais duro". Aconselhou João Cândido, pai de Chico, a ocupar o tempo livre do menino, arranjando-lhe um emprego. À época a fábrica de tecidos da cidade estava empregando crianças para trabalhar no período noturno. Chico X avier foi admitido: "Fui trabalhar como tecelão. Entrava às três da tarde, saía à uma da madrugada. D ormia até às seis, ia para a escola, saía às onze. Almoçava, dormia uma hora [...] e entrava de novo na fábrica" (Machado, 1992[1984]: 25-6). A rotina diária era estafante para uma criança de dez anos. Restava-lhe apenas o fim de semana para descanso e lazer. Algumas atividades, contudo, foram-lhe proibidas: 0 padre Scarzelli recomendou, como medida complementar, que se evitasse a "má influência" dos livros, revistas e jornais. Assentindo, João Cândido "fez uma fogueira das páginas proibidas" (: 18). Dizendo-se inconformado, Chico relata que recorreu, como sempre fazia, ao espírito da mãe. Esta lhe deu um conselho: "Aprenda a calar-se. Q uando lembrar, por exemplo, alguma lição ou experiência recebida em sonho, fique em silêncio. Mais tarde talvez você possa falar" (idem). Chico passou então a restringir seus comentários ao confessionário. Mas o padre Scarzelli insistia: "Ninguém volta a conversar depois da morte" (idem). E acrescentava: "O demônio procura perturbar-lhe o caminho" (idem). Chico, porém, não se deixava convencer: "Mas padre, foi minha mãe quem veio" (idem). 0 padre retrucava: "Foi o demônio" (idem). 
Os exemplos poderiam continuar sendo multiplicados, mas os acima apresentados parecem ser suficientes para evidenciar o peso e significado da interpretação institucional, católica, do fenômeno mediúnico nos meios populares à época. A convergência de leigos e eclesiásticos na interpretação do fenômeno mediúnico chama atenção, considerando-se que o pároco e a madrinha de Chico Xavier o entendem da mesma forma, isto é, como "coisa do diabo". Essa convergência se manifesta também quanto às atitudes assumidas em relação ao fenômeno da mediunidade: ambos entendiam ser preciso reprimi-lo, inibir sua manifestação, num caso por meio de castigos corporais, noutro pela oração e penitência.

Confrontando-se na sua experiência cotidiana com esse caráter prescritivo do Catolicismo oficial em relação ao fenômeno da mediunidade, Chico Xavier desenvolveu nessa etapa inicial de sua trajetória uma relação ambígua com as crenças católicas: sua "carolice de infância" se desenvolveu permeada de experiências que fogem ou são reprimidas pelo Catolicismo oficial, resultando em conflitos pessoais, tanto com representantes da Igreja, como com membros do universo de suas relações de sociabilidade primária.

\section{A conversão}

Transição de natureza marcadamente simbólica, a conversão de Chico Xavier ao Espiritismo ocorreu a partir da experiência de cura de uma sua irmã, realizada por um casal espírita, depois de sucessivos tratamentos médicos malsucedidos visando o controle de seus "acessos de loucura". Então com 17 anos, Chico Xavier participou das orações e passes, sendo em seguida introduzido à obra de Allan Kardec. A narrativa desse fato ao pároco e a decisão de seguir a nova doutrina marcaram o seu desligamento oficial do Catolicismo. Antes, porém, Chico Xavier buscou a bênção do padre: 
SAndra Jacqueline Stoll. Religião, CiÊnCia ou aUto-ajuda?

Eu respondi [...] que apesar de respeitá-lo muito, ia estudar o Espiritismo e dedicar-me à mediunidade. Ele permaneceu calado [...]. Pedi a ele que me estendesse a mão [...]. D epois de beijá-la, pedi que me abençoasse. Ele, então, me disse: "Seja feliz, meu filho. Eu rogarei à nossa Mãe Santíssima para que te abençoe e proteja [...]" . Levantei-me e saí, sabendo que havia tomado a decisão de praticar a mediunidade; quando cheguei à porta, volteime para vêlo ainda uma vez, notei que ele [...] me acompanhava com o olhar e sorria. (Barbosa 1992 [1967]: 29)

A mudança de tutoria constitui, nesse caso, uma das marcas fundamentais do trânsito religioso. Como demonstram os dados acima, até então a tutela espiritual de Chico X avier vinha sendo exercida pela mãe, "em espírito", e pelo padre. Essa dualidade foi eliminada com a conversão religiosa, estabelecendo-se a partir daí a sujeição exclusiva à tutela dos espíritos. Ritualmente a mudança foi marcada pela substituição do vínculo de consangüinidade (mãe/ filho) pelo vínculo de parentesco simbólico, selado na relação de apadrinhamento estabelecida entre médium e guia espiritual. Este último, no entanto, não se identificou de imediato. Segundo relato de Chico Xavier, Emmanuel se manteve incógnito por quatro anos (de 1927 a 1931), período considerado de treinamento de sua mediunidade, em especial da prática da psicografia.

Fase liminar, característica dos processos iniciáticos, essa etapa foi marcada pela produção anônima, envolvendo dupla iniciação: além do desenvolvimento da escrita mediúnica, as mensagens psicografadas promoveram a familiarização de Chico X avier com um "discurso de virtudes", que incisivamente remetia à questão da obediência, da paciência e da humildade. Esses temas, que até então haviam sido objeto de orientação materna como solução para os conflitos familiares, passaram a partir de então a promover a formatação de sua personalidade pública.

Um "contrato de trabalho", visando a produção de livros mediúnicos selou, a partir de 1931, a relação entre médium e guia espiritual. Chico X avier conta que se encontrava num final de tarde em orações à beira de um açude, localizado à saída da cidade, quando avistou um espírito 
Revista de Antropologia, São Paulo, USP, 2002, v. 45 nํำ.

"envergando uma túnica semelhante à dos sacerdotes" que a ele se apresentou: "Está mesmo disposto a trabalhar na mediunidade?", perguntou. "O senhor acha que estou em condições de aceitar o compromisso?", retrucou o médium. 0 espírito respondeu: "Perfeitamente, desde que respeite três pontos básicos". Chico perguntou: "Q ual o primeiro ponto?" Resposta: "Disciplina". "E o segundo?” "Disciplina”. "O terceiro?" "D isciplina" (G ama 1995 [1955]: 64).

A ceito os termos do contrato, desenvolveu-se entre ambos uma relação de maior abrangência: duradoura, cotidiana, sobretudo, disciplinadora. As tensões que emergiam de início em função da divergência entre pretensões, projetos e/ ou decisões pessoais do médium e a vontade dos espíritos evidenciam como se deu o processo de seu treinamento disciplinar, abrangendo as mais variadas dimensões de sua vida cotidiana. Segundo seu próprio relato, o seu tempo passou a ser dividido entre o trabalho remunerado e as atividades noturnas e de fim de semana no centro. Restavam-lhe poucos momentos de lazer. Conversas numa roda de amigos eram raras.

Chico Xavier afirma que a postura de E mmanuel era implacável em todas as situações. Inclusive diante das dificuldades econômicas por ele enfrentadas. Ele conta que em 1939 um grupo de cientistas russos lhe fez uma oferta: convidaram-no a passar seis meses em Moscou, com 0 fim de realizar testes sobre sua mediunidade. A oferta parecia tentadora: "o dinheiro era suficiente para construir cinqüenta casas populares. Uma fortuna para quem estava às voltas com a primeira de oito prestações de um novo chapéu" (Souto Maior, 1995: 56). Mas Emmanuel foi logo pondo fim às suas pretensões: "Se quiser, pode ir disse ele - eu fico". Igualmente rigorosa foi sua conduta em relação aos problemas de saúde do médium.

Chico Xavier conta que, uma noite, estava psicografando quando "sentiu o olho esquerdo invadido por fragmentos de areia" (: 29). Esfregou-o "mas a coceira continuou. Tentou fixar a lâmpada com a pupila incomodada, mas em vez da luz acesa viu um foco difuso. Mal con- 
seguia enxergar os versos récem-escritos”. A ssustado recorreu, como sempre fazia, à oração. A pareceu-lhe o "dr. Bezerra de Menezes ${ }^{20 "}$, que pouco depois informou: "Sua vista amoleceu por razões que não podemos saber agora. Prepare-se para ir a tratamento em Belo Horizonte, para que sua família não diga que você ficou sem se tratar por nossa causa" (: 29). D ois dias depois, soube do diagnóstico oficial: "Isso é um tipo de catarata [...] inoperável" (idem). Chico Xavier tinha então apenas 21 anos. Ele decidiu consultar Emmanuel a respeito. "Tenha serenidade, [...] você está sob cuidado dos benfeitores espirituais e sob a assistência de médicos atenciosos e amigos" (Barbosa, 1992 [1967]: 85), disse-lhe o espírito. “Quer dizer que preciso tratar-me?” (idem), perguntou Chico desapontado, acrescentando em seguida: "O senhor quer dizer que embora eu seja médium [...] não posso esperar a intervenção do Plano Espiritual em meu benefício para curar-me?” (idem). Emmanuel retrucou:

Porque você receberia privilégios por ser médium? [...] a condição de médium não exonera você da necessidade de lutar e sofrer, em seu próprio benefício, como acontece às outras criaturas que estão no Plano Físico. (Idem)

Chico Xavier não se resignou de imediato. Perguntou como poderia desenvolver a tarefa de escrita dos livros espíritas, que apenas se iniciava, se a deficiência visual de que era portador dificultava-lhe o trabalho. D isse-lhe o guia: "Confie no Senhor, pois sua doença é arrimo que ele enviou em seu auxílio" (: 86). Chico alegrou-se imediatamente: "Então Jesus vai curar-me?" (idem). Ele mesmo prossegue 0 relato:

Emmanuel me fitou [...] e mandou que eu abrisse 0 evangelho segundo 0 E spiritismo, no capítulo VI [...]. Então comecei a ler em voz alta [...]. Q uando atingi a palavra "aliviarei" , nosso Amigo Espiritual sustou-me a leitura e disse: "Compreendeu bem?Jesus não promete curar-nos, isto é, retirar-nos [...] das obrigações que nos cabe cumprir perante as leis de $\mathrm{D}$ eus mas promete aliviar-nos e auxiliar-nos. (Idem) 
Revista de Antropologia, São Paulo, USP, 2002, v. 45 noㅡ.

Sem outra alternativa, Chico X avier afinal deixou-se convencer: "Resignei-me", disse ele (idem).

Anos mais tarde, quando perguntado sobre a doença nos olhos, dizia: "Todo médium tem seus testes" (: 47). Ou então afirmava: "Eu não poderia escapar. Ainda hoje devo sofrer para aprender" (idem). Houve também ocasiões em que fez suas as palavras de Emmanuel, como, por exemplo, nessa entrevista: "D ecerto o Mundo Espiritual permite que eu passe por [...] provações para mostrar-me que receber livros [...] não me cria privilégio algum" (: 32).

Revendo mais tarde sua trajetória, ele assim a resumiu: "Emmanuel tenta adaptar-me para a colaboração com ele, desde 1931 até agora, assim como um viajante [que] procura domar um animal freado e irrequie to, a fim de realizar uma longa excursão" (: 66; destaque meu).

$\mathrm{O}$ modo como Chico Xavier retrata o processo de sua conversão e assujeitamento à vontade dos espíritos permite observar que a produção da liminaridade, característica dessa fase, expressa-se tanto por gestos de ruptura, como de continuidade em relação à filiação religiosa de origem. 0 modo de construção da relação entre médium e guia espiritual é exemplar especialmente com relação a esse último aspecto: de um lado, essa relação ritual se inscreve nos termos do parentesco simbólico, traduzindo-se 0 apadrinhamento numa relação de proteção de tipo filial, o que remete ao modelo santorial próprio do Catolicismo popular; de outro, o aporte institucional, eclesiástico católico, também aparece como fundamento da autoridade do espírito-guia. Além do preceito institucional da obediência, que inscreve essa relação, a própria imagem do guia, divulgada pelos espíritas, remete ao modelo institucional católico. Basta observar as fotos reproduzidas em livros espíritas a partir da narrativa de Chico Xavier: nestas Emmanuel aparece sempre com vestes sacerdortais, semelhantes às de um padre jesuíta $^{21}$. O s trajes que ele ostenta (uma espécie de batina preta) assim como a rígida disciplina de trabalho e de vida que impôs ao médium são típicas desse aporte institucional. 
D onde se pode afirmar que nessa primeira etapa do percurso iniciático de Chico Xavier a experiência da conversão é construída a partir de um duplo sincretismo com a tradição católica. Na etapa seguinte, porém, prevalece a interlocução com o modelo institucional, como se verá a seguir.

\section{Vida de santo}

Num seu trabalho recente, Le G off (2001) define São Francisco de Assis como figura de transição entre o medieval e o moderno, sugerindo ter sido uma de suas contribuições a renovação da santidade católica a partir de seu estilo de vida e de apostolado. Em suas palavras: "Tomando e dando como modelo o próprio Cristo e não mais seus apóstolos, ele comprometeu o cristianismo com uma imitação do D eus-Homem" (: 13-4). Além disso, combateu o modelo eremítico de santidade, vigente desde o século IV: "Vencendo ele próprio a tentação da solidão [foi viver em] meio da sociedade [...], nas cidades e não nos desertos, nas florestas ou no campo" (: 13-4). Essas inovações introduzidas implicaram a constituição do espaço públio e da vida otidiana em "esfera de salvação". Com relação a esse último aspecto - a santificação da vida cotidiana - , observa-se, porém, tendência à preservação de práticas institucionais estabelecidas. Segundo Le G off, os escritos de São Francisco exortam a necessidade de "respeitar os três votos: de obediência, de pobreza e castidade" (: 93).

O "itinerário de santidade" (Certeau, 1982) de Chico Xavier segue esse mesmo modelo, o que significa que a narrativa de sua vida e carreira religiosa encenam uma noção de santidade que, a exemplo de São Francisco de Assis, "se manifestam menos por milagres [...] e pela exibição de virtudes, do que pela linha geral de uma vida totalmente exemplar", conforme sugere Le G off (: 43).

Para Chico Xavier, como outros santos, a constituição dessa vida santificada não transcorreu, porém, sem hesitações, incertezas, dificuldades. Sua narrativa, de início, é, portanto, freqüentemente marcada pelo 
Revista de Antropologia, São Paulo, USP, 2002, v. 45 noㅡ.

lamento. Mas com o tempo ele próprio começa a produzir provas de humildade, um dos preceitos básicos da vida de santo. Trata-se de um ideal de comportamento, que deve se manifestar publicamente de várias formas, inclusive como modo de auto-representação, como indicam alguns dos exemplos acima mencionados.

A renúncia complementa esse modelo de construção da vida de santo. Nesse caso, porém, ela não se manifesta por meio do retiro da sociedade e, sim, pela criação de um estilo de vida sui generis, cuja marca de separação consiste na oposição a certos valores culturais e práticas correntes em seu meio social. Os relatos biográficos de Chico Xavier evidenciam que essa construção de uma vida santificada não teve o mérito da inovação. Em larga medida ele a produziu inspirando-se no modelo monástico de virtuosidade católica, para o qual constitui preceito fundamental a renúncia ao sexo, ao casamento e a bens materiais:

Para que os livros nascessem de minhas pobres faculdades, de modo mais intenso [...] foi preciso, diz-nos Emmanuel, que eu aceitasse a existência em que me encontro, na qual o matrimônio [...] não seria possível. Isto não quer dizer que a mediunidade crie antagonismos entre médium e casamento terrestre, mas sim que determinadas tarefas mediúnicas requisitam condições especiais para que se façam cumpridas. (Folha Espírita, nov. 1976, apud Nobre, 1996: 145)

A renúncia ao matrimônio como condição de realização plena da potencialidade mediúnica sugere a concepção cristã do sacerdócio. No depoimento de Chico Xavier, como no de outros médiuns (cf. D antas, 1988; Rodrigues, 1987; Prandi, 1996), observa-se que a imposição da castidade legitima a releitura da própria biografia como a história de uma eleição. O s relatos consultados evidenciam, porém, que a tendência de Chico Xavier ao celibato se configurou, a princípio, independente da questão mediúnica.

Na fase adulta, o tema passou do circuito familiar à especulação pública. Os boatos, muitas vezes contraditórios, corriam com freqüência na imprensa. "Boatos de [um] possível casamento", afirma Schubert, 
SAndra JacQueline Stoll. Religião, ciênCia ou AUto-AJuda?

"aconteceram mais de uma vez" (1986: 297). A maioria das especulações, no entanto, girava em torno da suposta homossexualidade do médium. A fala fina e mansa, complementada por maneiras delicadas, alimentou com freqüência insinuações a respeito. Chico X avier, porém, jamais aceitou o rótulo de homossexual. Celibatário convicto, ele inúmeras vezes explicitou essa sua condição. Ele se defendia de insinuações a respeito de sua conduta sexual recorrendo a frases feitas: "De que vale um perfume preso a um frasco?" (Souto Maior, 1995: 74). O u então: "Por que ficar preso a uma mulher?" (idem). Fazendo uso dos mesmos argumentos de que se serve o clero católico, por vezes dizia: "minha família é a humanidade" (idem).

Capitalizadas simbolicamente, as práticas do celibato e da castidade foram no decorrer do tempo ressignificadas, transformando-se de componente da personalidade do médium em forma de expressão modelar da mediunidade espírita. Não sendo esta, porém, uma norma doutrinária, o que esse percurso sinaliza é a apropriação por Chico Xavier de práticas institucionais de construção da santidade católica.

0 mesmo se observa no que se refere à relação com bens materiais. A experiência de pobreza veio-lhe de berço. Mas o desapego aos bens materiais, como forma de sinalizar distanciamento das "coisas do mundo", foi uma experiência construída, referenciada no voto de pobreza católico. D os relatos de Chico Xavier se depreende que este pouco desfrutou, em mais de 90 anos de existência, das benesses do chamado "mundo moderno". A princípio, em conseqüência das restrições financeiras que caracterizaram as condições de vida de sua família. Mais tarde, por opção pessoal: seus livros psicografados, traduzidos em várias línguas, renderam milhões em direitos autorais. Ele, contudo, nunca se apropriou de qualquer parcela desses rendimentos. $O$ ficialmente, por meio de registro em cartório, doou os proventos dos livros mediúnicos às editoras de seus livros, bem como a inúmeras obras sociais. Viveu sempre exclusivamente de seu minguado salário de funcionário público de baixo escalão. Como prova de gratidão, muita gente chegou a 
lhe oferecer dinheiro. Chico recusava sistematicamente: "Ajude o primeiro necessitado que encontrar", dizia ele. 0 mesmo fazia com os presentes com que era agraciado. Sistematicamente recusou também doações que lhe foram feitas, envolvendo terras e dinheiro. Tudo foi repassado a instituições de caridade.

Complementa esse exercício de renúncia, a prática da caridade, cujas formas introduzidas por Chico Xavier se tornaram, mais tarde, modelares para a prática espírita. Também com relação a essas se observa inspiração em práticas institucionais católicas. É o caso da peregrinaçao, denominação dada por Chico Xavier às visitas semanais que realizava, aos sábados à tarde, a famílias que viviam embaixo de uma ponte em Pedro Leopoldo. Acompanhado de um grupo de amigos, ele lhes levava doações feitas durante a semana em roupas e alimentos. 0 cenário urbano servia-lhe, assim, de palco para a pregação do Evangelho. Em Uberaba, onde ele se estabeleceu alguns anos mais tarde, essa atividade se estendeu também aos bairros de periferia. Realizadas ao ar livre, suas pregações se tornaram famosas. Essa atividade "extramuros" era complementada com as visitas a doentes em hospitais e a presidiários. Ao contrário dos evangélicos, porém, Chico Xavier não fazia pregações: "Não poderia aproveitar que eles estão atrás de grades para fazer sermão" (Souto Maior,1995: 218). Finalmente, à época do Natal, saía em caravana de carros pelos bairros de periferia distribuindo presentes.

No bojo dessas práticas insinua-se a idéia de que a santidade como modo de vida se realiza por meio da prática de doação. Este é um elementochave da ética cristã da santidade: enquanto os demais fazem e acumulam para si (ou para os seus), o santo é aquele que acumula gestos e práticas de doação aos outros. Esse ideal se realiza a partir de padrões culturais, podendo concretizar-se, portanto, de formas variadas. $\mathrm{O}$ que distingue a santidade espírita no Brasil, concretizada pela vida de Chico Xavier, é o éthos institucional católico de que esta se impregnou ${ }^{22}$. 


\section{O Espinitismo no Brasil: versões concorrentes}

"Santidade", afirma Rubem C. Fernandes, "é um tema maior da religiosidade brasileira" (1994: 197). Sua importância é de tal ordem que no Catolicismo "ouve-se costumeiramentefalar em 'Santa Trindade', 'São Bom Jesus', 'Festa do Divino'" (idem). Segundo o autor, "pelas artes do sincretismo", essa noção estendeu-se também a outros universos religiosos.

As divindades africanas de origem ioruba, os orixás, também são chamados costumeiramente de santos. Com efeito, os fiéis afro-brasileiros são referidos como "povo do santo" ediz-se de alguém iniciado que ele ou ela "é do santo". O s pentecostais assimilam a palavra evangélica "sede santos como eu sou santo" e distinguem-se entre as denominações protestantes pela ênfase na presença ativa do Espírito Santo. (Idem)

O Espiritismo também não foge à regra, se considerarmos que Chico $\mathrm{X}$ avier, seu personagem-símbolo, tornou-se conhecido, dentro e fora do âmbito espírita, como um "homem santo".

Resistências a esse modelo de expressão do Espiritismo brasileiro, no entanto, começaram a se delinear especialmente a partir dos anos 80. Configurando tendências ainda em construção, essas novas correntes se apresentam como outras leituras da tradição. 0 ponto comum entre elas, parece-me, reside na busca de afastamento da leitura católica de que se impregnou o Espiritismo com Chico Xavier. Na maioria dos casos a estratégia adotada consiste na constituição de outros interlocutores, dentro e fora do campo religioso, resultando, em conseqüência, a possibilidade de se trilhar caminhos diversos, como ocorreu, por exemplo, com Waldo Vieira e Luiz Antonio Gasparetto. 0 primeiro, depois de abandonar a prática espírita, envolveu-se na organização de um movimento de cunho paracientífico (a chamada Projeciologia, posteriormente renomeada Conscienciologia), ao passo que Luiz Antonio Gasparetto procurou promover a inovação da doutrina por meio da síntese desta com idéias e práticas de auto-ajuda e do universo da chamada Nova Era. 
Revista de Antropologia, São Paulo, USP, 2002, v. 45 nํㅡ.

D 'Andrea (2000) sugere que o aumento do número de adeptos do Espiritismo ocorrido nos últimos anos está intimamente associado a essa fragmentação do movimento, ocorrida nas últimas décadas. Segundo esse autor, o processo de fragmentação do Espiritismo resultou da incapacidade deste em atender a demandas divergentes de segmentos da população que se diferenciam "especialmente no que tange a estilos de vida, articulados com níveis de renda" (: 136). 0 ponto crucial, acrescenta ele, consiste nas "pressões [...] e necessidades [...] de indivíduos de classe média alta [que] se chocam com o excessivo tradicionalismo e intelectualismo dogmático das instituições kardecistas oficiais" (: 139).

Protagonistas desse movimento, os dois personagens citados têm capitalizado essas demandas, juntamente a outros grupos e lideranças. As alternativas por eles construídas expressam, de forma exemplar, duas tendências dominantes, que podem ser observadas também em outros contextos nacionais: a busca de aproximação com a ciência, de um lado; o estabelecimento de interlocução com grupos, seitas e práticas que remetem ao ideário da chamada Nova Era, de outro. No presente caso a trajetória de Waldo Vieira ilustra a primeira alternativa, enquanto 0 percurso de Luiz G asparetto ilustra a segunda. No que segue apresento uma síntese do percurso desses dois personagens, de forma a delinear com mais precisão a construção dessas duas alternativas, surgidas do confronto com o viés católico assumido pelo Espiritismo no Brasil.

\section{Waldo Vieira: entre a religião e a ciência ${ }^{23}$}

Conhecido no meio espírita pela produção de livros em co-autoria com Chico Xavier, Waldo Vieira realizou um percurso que pode ser balizado em dois momentos: 0 primeiro, aquele de sua juventude, compreende o período em que desenvolveu a prática mediúnica sob a liderança e na companhia de Chico Xavier; a ruptura com o Espiritismo, em meados dos anos 60, marca a segunda etapa, fase em que, depois de dedi- 
SAndra JacQueline Stoll. Religião, ciênCia ou AUto-AJuda?

car-se ao estudo da medicina, decide investir numa carreira solo, assumindo, alguns anos mais tarde, a liderança de um grupo voltado à prática de "experiências fora do corpo" (ou "viagem astral" como a denominam os espíritas). Conhecido pelo nome de Projeciologia, esse grupo fundado e liderado por Waldo Vieira teve o seu desenvolvimento desdobrado em duas fases: na primeira, segundo D 'Andrea (1981) que realizou estudo de caso sobre o tema, predomina a construção carismática da imagem pública de sua liderança; a outra, mais recente, envolve a institucionalização e burocratização organizacional do grupo.

Assim como outras correntes que integram o universo das chamadas paraciências, a Projeciologia se caracteriza pela pretensão de promover uma síntese entre saberes científicos e não-científicos. Tratase, portanto, da construção de um pensamento de cunho secular sobre fenômenos que, no senso comum, são tidos como próprios do domínio religioso. Neste caso, o objeto-alvo de produção de conhecimento é a experiência de consciência "fora do corpo físico".

Fundador do Instituto Internacional de Projeciologia e Conscienciologia, Waldo Vieira começou a divulgar sua experiência pessoal e conhecimentos sobre o tema por meio da realização de palestras públicas e da produção de livros. O s mais conhecidos dentre estes últimos foram lançados nas últimas décadas, com um intervalo de aproximadamente dez anos: Projeciologia: panorama das ex periências da consciência fora do corpo humano foi publicado em 1986; 700 ex perimentos de C onscienciologia foi lançado em 1994. Nesse ínterim, entre uma publicação e outra, deuse a institucionalização do movimento. Segundo D'Andrea esse processo foi conduzido por Waldo Vieira por meio da realização de cursos de treinamento, visando a formação de professores. Criando por meio desse expediente uma ampla rede de disseminadores de suas idéias, Waldo Vieira passou a ter nestes "profissionais" uma base para a disseminação de núcleos de estudo e pesquisa, os quais se encontram hoje espalhados no Brasil e no exterior. 
Revista de Antropologia, São Paulo, USP, 2002, v. 45 nํำ.

O bserva D 'Andrea que esse processo de disseminação não atinge, contudo, a produção intelectual, que permanece sendo monopólio de seu fundador.

O estilo de liderança adotado é de tipo carismático: à semelhança de certos gurus indianos, Waldo Vieira usa uma vasta barba (branca), veste-se sempre de branco e ostenta, para além de traços distintivos de aparência, certos dons, dentre eles a mediunidade, a projetibilidade, a clarividência e a manipulação de energias para cura e materializações. A essas faculdades se soma ainda, como fator de distinção, a ostentação de sua condição de médico. A formação acadêmica serve nesse caso não apenas como fator de prestígio, mas, também, como suporte para a pretensão de cientificidade que reinvidica para a sua produção.

Com relação a esse último aspecto observa-se que a tentativa de aproximação do campo científico se realiza basicamente por meio de dois expedientes: 1) ênfase no experimentalismo, prática que envolve o desenvolvimento e a catalogação de técnicas de produção da projetibilidade, isto é, da capacidade de "sair do corpo"; e 2) investimento na construção de um universo conceitual singular. 0 rebuscamento lingüístico se apresenta como índice desse layout pretensamente científico, o qual se caracteriza pela criação de palavras, supostamente novas, que gradativamente vão sendo agregadas a um repertório cujo traço marcante é estar sempre em construção ${ }^{24}$. A própria mudança de denominação do grupo para Conscienciologia se insere nessa lógica. Sendo seu objetivo é expresso nos seguintes termos: trata-se de um movimento que visa o "estudo da consciência (a partir de uma) abordagem integral, holossomática, multidimensional, bioenergética, projetiva, autoconsciente e cosmoética" (D'Andrea, 2000: 164; destaques meus).

Concebido como "índice de racionalidade", esse investimento de ordem lingüística visa marcar, simbolicamente, o distanciamento de Waldo Vieira de outros sistemas de idéias, que operam essas mesmas práticas, tendo porém como fundamento orientações tradicionais, doutrinárias. 0 intenso investimento na organização burocrático-adminis- 
SAndra Jacqueline Stoll. Religião, ciênCia ou AUto-AJUda?

trativa, implementada por ele especialmente nos últimos anos, tem esse mesmo sentido: os padrões de racionalidade, eficiência e profissionalismo adotados visam, dentre outros, marcar seu distanciamento do campo religioso ${ }^{25}$.

É interessante observar nessa trajetória a tendência à aproximação daquele que era o projeto de Allan Kardec, isto é, fazer do Espiritismo uma doutrina científica. Essa mesma intenção mobiliza Waldo Vieira com relação à Projeciologia, projeto que o distancia definitivamente da tradição espírita, em especial da interpretação religiosa consolidada sob a liderança de Chico Xavier. Como resultado tem-se, portanto, um deslizamento, isto é, a constituição de uma corrente dissidente, que assume como característica básica o deslocamento da ênfase no aspecto moral em favor do experimentalismo ${ }^{26}$.

Waldo Vieira sinaliza dessa forma um afastamento da tradição religiosa que marcou a sua iniciação. O s sinais diacríticos utilizados remetem simbolicamente à modernidade, cujo discurso tem na racionalidade um de seus valores fundamentais. Esses valores são explicitados de duas formas: por meio da produção discursiva e da ênfase que vem sendo dada nos anos mais recentes à organização burocrática.

\section{Luiz Antonio Gasparetto: entre o Espinitismo, a auto-ajuda e a cosmologia new age}

Luiz Antonio Gasparetto seguiu caminho oposto ao de Waldo Vieira, realizando um percurso que é emblemático do carnavaleso, termo empregado aqui tal como utilizado por Da Matta (1981). Sua trajetória segue, em princípio, o mesmo modelo acima observado: a primeira fase é marcada por forte influência de Chico X avier e da Federação E spírita Brasileira; a segunda envolve o desenvolvimento de um percurso voltado à inovação, prática que, "pelas artes do sincretismo", se concretiza por meio da incorporação de idéias e práticas de auto-ajuda e do universo da chamada Nova Era. 
Revista de Antro pologia, São Paulo, USP, 2002, v. 45 nํำ.

Este é, portanto, um percurso que implica, como no caso anterior, em distanciamento da tradição, embora não configure, como no caso de Waldo Vieira, um total rompimento com o Espiritismo ${ }^{27}$.

Os anos 80 constituem nesse caso o marco da mudança. Por essa época Luiz G asparetto realizou uma série de viagens à Europa e aos Estados Unidos com a finalidade de promover a divulgação do Espiritismo. As sessões públicas de pintura mediúnica e programas de TV de que participou the permitiram observar a atuação de outros médiuns. Numa dessas viagens esteve também em Esalem, o centro new age da Califómia (EUA), onde entrou em contato com idéias e práticas de diversos sistemas de conhecimento, especialmente com o então chamado "pensamento positivo" e técnicas de psicoterapia corporal. De volta ao Brasil, Luiz G asparetto começou a se indispor com a Federação Espírita Brasileira. $\mathrm{O}$ alvo principal de suas críticas era dirigido ao moralismo espírita, manifesto, entre outros, no tratamento de certos temas, sexo e dinheiro, por exemplo.

Q uando viajo para o estrangeiro e converso com os médiuns, os espíritos conversam abertamente de sexo e seus problemas. Aqui não. No Brasil nenhum espírito toca nesse assunto [...]. Aqui só dizem: "vai tomar passe, vai tomar passe!" [...] "apesar dos espíritos terem tentado passar uma mensagem libertadora, aqui os médiuns eram católicos e a linguagem que usaram era própria de sua estrutura mental. Passou o que foi possível. 0 resto ficou cheio de catolicismo. (Apud Stoll, 1999: 46)

Pouco tempo depois, aliando sua formação de psicólogo à experiência mediúnica, Luiz Gasparetto acabou criando um espaço alternativo de trabalho. Inaugurado em São Paulo nos anos 80, o Espaço Vida e Consciência passou a integrar o circuito dos espaços neo-esotéricos da cidade. Suas atividades regulares são cursos e palestras, às quais se somam shows e work shops, realizados eventualmente.

Por muitos anos Luiz $\mathrm{G}$ asparetto se dividiu entre essas atividades e o exercício da prática da pintura mediúnica no centro O s Caminheiros, 
Sandra Jacqueline Stoll. Religião, ciênCia ou auto-ajuda?

dirigido pela sua mãe, Zíbia Gasparetto. Por mais de dez anos a complementaridade definiu o trabalho realizado nesses dois espaços. O u seja: no centro as atividades obedeciam ao padrão espírita tradicional (realização de sessões públicas de pintura mediúnica e aconselhamento; manutenção de uma creche a título de trabalho de caridade; destinação dos recursos financeiros, oriundos das atividades mediúnicas da família, para esta última); por sua vez, no Espaço Vida e Consciência, local definido como de exercício de atividade de cunho profissional, predominava a realização de atividades em caráter experimental, destacando-se entre estas, cursos e práticas voltados à questão da autoajuda. Com essa perspectiva Luiz G asparetto explorou, nesse "espaço", as mais diversas linguagens. Além de novos usos dados à pintura mediúnica, como o de objeto de cenografia para seus shows, verificase a utilização de práticas discursivas diversas, incorporando-se ao seu repertório o uso da música, da expressão corporal, de técnicas de relaxamento e do psicodrama, bem como da representação teatral.

A divulgação das atividades desenvolvidas nesses dois "espaços" contou com recursos diversos de mídia, destacando-se dentre eles os programas de rádio que nos últimos anos passaram a ser diários. Protagonizados pelo próprio médium, Luiz Gasparetto, nos últimos anos estes passaram a contar, às segundas-feiras, com a participação de Zíbia Gasparetto, mãe de Luiz, cuja presença tem sido uma constante nas listas dos livros de auto-ajuda ou não-ficção mais vendidos.

Essa duplicidade dos "espaços" e das atividades desenvolvidas - uma caracterizada como profissional, a outra como mediúnica - mantevese por mais de uma década, tendo sido preservada, em larga medida, em função da restrição dos espíritas quanto à remuneração da atividade mediúnica.

Como outras já citadas, essa reinterpretação espírita da tradição cristã tem em Chico Xavier um modelo exemplar. Tensões crescentes em relação a esse modelo, moral e ético, levaram afinal a família $\mathrm{G}$ asparetto ao rompimento com a prática institucional espírita, fato consumado em 
Revista de Antropologia, São Paulo, USP, 2002, v. 45 nํำ.

1995, quando se decidiu encerrar as atividades do centro Os Caminheiros. Essa decisão, assumida publicamente como resultado da "orientação dos espíritos", abriu caminho para se promover, com mais liberdade, 0 uso da mediunidade com fins lucrativos. Um primeiro passo nessa direção fora dado anteriormente, quando se decidiu fechar a editora do centro Os Caminheiros. A abertura de um novo selo, desvinculado do centro, tornou possível a apropriação dos direitos autorais de livros psicografados, prática condenada na tradição espírita. "Podemos fazer uma mediunidade moderna", disse G asparetto numa de suas palestras, sintetizando nessa fala a possibilidade do médium fazer uso da mediunidade visando o seu próprio bem-estar (inclusive financeiro), além de utilizá-la para a orientação dos indivíduos na solução de seus problemas cotidianos.

Esse afastamento do ideal kardecista da caridade caracteriza um deslizamento significativo com relação à tradição. A essa prática somase ainda, neste caso, a reintepretação da noção de karma de uma forma mais positiva, permitindo assim a passagem da ética da caridade que implica a noção de doação como sacrifício - para a ética da prospe ridade - tema do repertório neo-esotérico e de auto-ajuda, que tem como objeto a questão do bem-estar dos indivíduos, aqui e agora.

0 percurso trilhado por Luiz G asparetto descreve, portanto, um modo particular de produção da inovação da tradição espírita, sem implicar um total rompimento com esta, como no caso de Waldo Vieira. Isso porque o uso da mediunidade em moldes espíritas continua sendo a forma de produção da mediação entre este e o "outro mundo", prática religiosa que se mantém como fonte de autoridade das práticas e idéias que o grupo sustenta. Trata-se, portanto, de um outro modo de "ser espírita" menos convencional, menos constrangido pelo moralismo católico, mais afeito ao experimentalismo no que diz respeito ao uso de linguagens, de técnicas de comunicação, e mais voltado às questões de ordem psicológica.

Retomando, enfim, o argumento de início, esse "sistema de personagens" sugere serem diversos os modos de produção da fragmenta- 
ção do campo espírita, que a colocam, cada um a seu modo, a tradição sob "riscos empíricos" (cf. Sahlins, 1990). Um dos resultados produzidos é o alargamento do campo das interlocuções estabelecidas: os casos apresentados sugerem um processo de redefinição das margens de trânsito, confronto e aliança, tanto dentro como fora do campo religioso. No que se refere ao aspecto da crítica ao sincretismo católico, este movimento se coaduna com o que alguns autores observam em relação a certos segmentos do Candomblée ${ }^{28}$. No entanto, as respostas apresentadas pelo Espiritismo parecem ter um espectro mais amplo, uma vez que estas incluem tanto projetos que visam o distanciamento completo de um viés religioso - caso dos grupos que, a exemplo de Waldo Vieira, buscam uma reaproximação da ciência - , como grupos ou movimentos que buscam a renovação das idéias e práticas espíritas por meio do amálgama de possibilidades que oferece 0 chamado universo neo-esotérico. D esse segundo movimento emerge um aspecto inovador, que consiste na abertura de um novo campo de diálogo no interior do campo religioso, na medida em que o ideário da prosperidade se apresenta como moeda moral que agrega segmentos tradicionais e novos do campo religioso, dentre eles, certas correntes do universo neoesotérico, do Espiritismo e das religiões neopentencostais, como a Igreja Universal do Reino de D eus.

\section{Notas}

1 Este ensaio condensa algumas das principais idéias que apresento em minha tese de doutorado em Antropologia Social, defendida na Universidade de São Paulo, intitulada E ntre dois mundos: 0 espiritismo da França eno Brasil (1999, mimeo.). Agradeço a José G uilherme Magnani, orientador, pelo estímulo constante e a Capes pelo financiamento das condições materiais para a realização desta pesquisa.

2 Esses dados foram obtidos em matérias de imprensa divulgadas à época pelas agências on-line: Isto É O nline; G loboN ews; Folha O nline; JB O nline. 
3 Publicado em 1932 pela Federação Espírita Brasileira, Parnaso de além-túmulo teve como primeiro comentarista o escritor ejornalista Humberto de Campos, que escreveu dois artigos no D iário Carioca. $\mathrm{O}$ jomal $0 \mathrm{G}$ lobo entrou no debate mais tarde. Em 1935 enviou um jornalista, Clementino de Alencar, a Pedro Leopoldo (MG ), onde vivia Chico Xavier, para investigar in loco a autenticidade de suas práticas mediúnicas. Publicadas semanalmente, as matérias desse jornalista ocuparam as páginas do jornal 0 G lobo por mais de um mês.

4 Os termos desse processo judicial bem como artigos de juristas e literatos que naépoca participaram dos debates foram compilados por Miguel Timponi (1978 [1959]). Para mais detalhes sobre esse episódio veja-se Stoll (1999).

5 Além de ser noticiado na imprensa espírita, o fato foi comentado com escárnio pelo $\mathrm{N}$ ational E nquire e pelo Physis $\mathrm{N}$ ews dos Estados Unidos. Apesar disso, outras mensagens psicografadas por Chico Xavier foram utilizadas como instrumento de defesa em dois outros processos, nos anos 80 (cf. Souto Maior, 1995: 207).

6 Matérias sensacionalistas ainda por vezes ocorrem, mas nestas os personagens centrais são hoje seus familiares, haja vista as recentes denúncias registradas na imprensa quanto aos maus tratos que o médium estaria sofrendo por parte destes, alguns dos quais também se acusa de estarem envolvidos no desvio de donativos destinados a instituições filantrópicas. A título de exemplo consultese a matéria "Casa da guerra. Filho adotivo e nora de Chico Xavier brigam por dinheiro" (V eja, 14 de fevereiro de 2001).

7 A íntegra do programa se encontra publicada sob o título Pinga-fogo œm Chiø X avier (São Paulo, Edicel, 1987).

8 O s trabalhos mais recentes produzidos sobre o tema incluem estudos de caráter histórico como o de D amazio (1994), predominando, porém, os estudos antropológicos, entre eles, Cavalcanti (1983), Giumbelli (1994) e D 'Andrea (1996 e 1997).

9 Veja-se Birman (1992 e 1994); Sanchis (1994a e 1994b); Mariz \& Machado (1994); Negrão (1997); dentre outros. 
10 A Livraria G amier, considerada à época a principal casa editorial do Rio de Janeiro, lançou o primeiro título, 0 livro dos espíritos, em português, em 1875. Isto é, 15 anos depois da segunda edição do mesmo na Europa. Segundo consta, o sucesso de público alcançado pela obra estimulou o lançamento pela Livraria G arnier, nesse mesmo ano, de dois outros títulos publicados por Allan Kardec: 0 livro dos médiuns (1861) e 0 ću e o inferno (1865). Cf. Machado (1983: 117).

11 Cândido Procópio Camargo publicou o primeiro título sobre o tema- Kardecismo eU mbanda - , em 1960. Mais tarde publicou um novo estudo, intitulado C atólicos, E spíritas e Protestantes (1963).

12 Roger Bastide escreveu primeiro um artigo, Spiritism au Brésil, publicado em A rchives des Sciensoes Sociales des Religions (24, juil.-dec. 1967). As idéias básicas deste artigo foram posteriormente reapresentadas num capítulo de A s religiões africanas no Brasil (1985 [1960]).

13 Para análise detalhada da produção desses autores a respeito do Espiritismo, assim como de outros que os sucederam no estudo desse tema, veja-se Stoll (1999: capítulo 2).

14 G iumbelli (1994) chama atenção no seu trabalho para a complexidade dessas relações fora do campo religioso, destacando em particular a interlocução entre 0 Espiritismo e os campos médico e jurídico no Brasil, entre 1890 e 1940.

15 Magnani (1999) sugere o uso do termo neo-esotérico em lugar de expressões correntes como "movimento Nova Era" (Amaral, 1998) ou "New Age" (D 'Andrea, 1996) na medida em que não se trata exatamente de um movimento articulado, mas de um conjunto de sistemas religiosos, filosofias e práticas de origens e matizes os mais diversos, cujos pontos de articulação estão em constante movimento e reconstrução.

16 A literatura espírita e acadêmica sustenta ter sido Bezerra de Meneses, fundador e primeiro presidente da Federação Espírita Brasileira, um dos principais responsáveis pela institucionalização da feição religiosa de que se revestiu o Espiritismo no Brasil. 0 papel de Chico Xavier parece-me, porém, fundador na medida em que sua exemplaridade o torna um modelo a ser seguido pelos adeptos da doutrina. 
17 "Palavras minhas", texto publicado na introdução de seu primeiro livro, Parnaso de além-túmulo (1932), descreve ainiciação de Chico Xavier na experiência e prática da mediunidade. "Explicando", publicado em E mmanuel (1938), relata o seu primeiro encontro com Emmanuel, seu guia-espiritiual.

18 Lembra Le G off a respeito de São Francisco de Assis que "o santo, em sua humildade, não trata de si próprio. Não se pode, portanto, esperar de sua obra [...] informação [...] sobre sua vida” (2001: 45). Quando isso ocorre, porém, como nos casos contados por Chico Xavier, a intenção é que estes sirvam "como exemplo" (idem).

19 Paraa construção dessemodelo narrativo baseio-me em Certeau (1982) e Beinert (1990).

20 Trata-se do espírito de Adolfo Bezerra de Meneses, morto em abril de 1900, no Rio de Janeiro. No meio espírita ele é reverenciado como um dos principais divulgadores da doutrina kardecista no século passado. Além de médico, jornalista e presidente da Federação Espírita Brasileira, ocupou cargos eletivos: foi vereador por duas gestões e elegeu-se deputado geral em 1867. Morreu aos 69 anos e, segundo os relatos registrados na bibliografia consultada, logo em seguida começou "a se manifestar" mediunicamente por meio de Chico Xavier. A sua relação com o médium não é historiada pela literatura consultada. Apenas se informa que foi por meio desse espírito que Chico Xavier praticava a atividade receitista.

21 Emmanuel, que se apresenta como espírito que teve algumas encamaçõesà época do Império Romano, segundo relato de Chico Xavier em sua última experiência terrena, foi o jesuíta Manoel da Nóbrega, um dos fundadores da cidade de São Paulo. Veja-se a esse respeito Costa e Silva (1995 [1977]); Tavares (1991 [1967]) e Machado (1983); dentre outros.

22 Afirma Da Matta sobre esse tema: "sabemos que o modelo de quem renuncia na sociedade ocidental éaquele encampado e legitimado pela Igreja, em sua incorporação do paradigma de Cristo" (1981: 207; destaque meu). Esse modelo permite, porém, segundo o autor, duas formas de aproximação: "A primeira é feita pela própria ideologia da Igreja Católica, com sua vida votiva de castidade (renúncia à reprodução e ao prazer físico), de pobreza (renúncias às glórias deste mundo) 
e de obediência (renúncia à própria individualidade) [...]. A segunda é feita com a política, quando em certas sociedades e circunstâncias históricas, o líder político que atinge 0 poder [...] apresenta-se como um sacrificado e verdadeiro renunciador das glórias desse mundo" (:207-8).

23 O s dados relativos à história pessoal e carreira de Waldo Vieira se baseiam no trabalho de D'Andrea (2000).

24 A constituição de um glossário é a base da produção literária de Waldo Vieira. Em geral, os conceitos por ele produzidos resultam de uma construção etimológica baseada na bricolagem de prefixos e sufixos de palavras preexistentes. É o caso de termos como, por exemplo, holopensene, que resulta da seguinte conjunção: holo=todo, pen=pensamento, sen=sentimento, ene=energia, ou seja, "um conjunto-padrão de pensamentos, sentimentos e energias" (apud D 'Andrea, 2000: 167), que se acredita influenciar todo e qualquer grupo de pessoas, "auxiliando-o ou prejudicando-o" (idem) conforme o contexto.

250 Instituto de Projeciologia apresenta organização administrativo-burocrática "complexa ealtamente departamentalizada". Seguindo moldes empresariais de estruturação, a "matriz" se liga uma rede de "filiadas"e "núcleos" espalhados pelo Brasil, assim como no exterior. Os seus dirigentes porém raramente são remunerados (cf. D 'Andrea, 2000: 165).

26 Observa D 'Andrea (: 171) que esse deslizamento perde força com o tempo: da mesma forma que ocorreu com Kardec, no movimento organizado porWaldo Vieira cresce, com o passar do tempo, a tendência à moralização do discurso.

27 Os dados sobre Luiz G asparetto constam de minha tese de doutorado, tendo sido obtidos por meio de pesquisa etnográfica e documental.

28 Sobre essa questão da busca de redefinição da identidade do Candomblébaiano veja-se os artigos de Consorte (1999) e Ferretti (1999), dentre outros. 


\section{Bibliografia}

AMARAL, L.

1998 Carnaval da A lma: comunidade, essência e sincretismo na N ova E ra, Rio de Janeiro, UFRJ/ PPGAS Museu Nacional.

AUBRÉE, M. \& LAPLANTINE, F.

1990 La table, les livres et l'esprits, Paris, J. C. Lattes.

BASTIDE, R.

1985 [1960] As religiões africanas no Brasil, São Paulo, Pioneira.

BEINERT, W.

1990 O culto aos santos hoje, São Paulo, Paulinas.

BIRMAN, P.

1992 "Modos periféricos de crença", in SANCHIS, P. (org.), C atoliaismo: unidade religiosa e pluralidade cultural, São Paulo, Loyola.

1994 "D estino dos homens e sacrifício animal: comparando carismáticos e pentecostais", Comunicacoues do ISE R, n. 45: 35-43.

1995 "Cultos de possessão e pentecostalismo no Brasil: passagens", R eligião eSociedade, n. 17: 90-109.

BRANDÃO, C.

1988

"Ser católico: dimensões brasileiras - um estudo sobre aatribuição de identidade através da religião", in: SACHS, V. ET AL, Brasil \& E U A : religião eidentidade nacional, Rio de Janeiro, $\mathrm{G}$ raal.

CAMARGO, C.P.

1961 Kardecismo eU mbanda, São Paulo, Pioneira.

1973 Católioos, espíritas e protestantes, Petrópolis, Vozes.

CAVALCANTI, M. L.

19830 mundo invisível. C osmologia, sistema ritual e a noção de pessoa no espiritismo, Rio de Janeiro, Zahar. 
CERTEAU, M. DE

1982

"Uma variante: a edificação hagiográfica”, in: A escrita da história, Rio de Janeiro, Forense-Universitária.

CONSORTE,J.G.

1999 "Em torno de um manifesto das Ialorixás baianas contra o sincretismo", in CARO SO , C. \& BACELAR, J. (orgs.), Fa@es da tradição afro-brasileira, São Paulo/ Salvador, Pallas/ Ceao.

DAMAZIO, S.

1994 D a elite ao povo: advento e ex pansão do espiritismo no Brasil, Rio de Janeiro, Bertrand Brasil.

D'ANDREA, A.

$1996 \quad 0$ self perfeito ea nova era: individualismo e reflex ividade em religiosidades pós-tradicionais, Rio de Janeiro, dissertação, Iuperj.

1997 Entre o Espiritismo e as Paraciências: o caso da Projeciologia e a Experiência Fora do Corpo, R eligião e Sociedade, 18.

$2000 \quad 0$ self perfeito ea $\mathrm{N}$ ova $\mathrm{E}$ ra. Individualismo ereflex ividade em religiosidades póstradicionais, São Paulo, Loyola.

DA MATTA, R.

1981 Carnaval, malandros e heróis. 3. ed. Rio de Janeiro, Zahar.

DANTAS, B. G.

1988 V ovó nagô e papai branco, Rio de Janeiro, Graal.

FERNANDES, R. C.

1994 "Santos e Agentes", in Romarias da paix ão, Rio de Janeiro, Rocco.

FERRETTI, S. F.

1999 "Sincretismo afro-brasileiro e resistência cultural", in CARO SO , C. \& BACELAR, J. (orgs.), Faøes da tradição afro-brasileira, São Paulo/ Salvador, Pallas/ Ceao. 
GEERTZ, C.

1994 [1968] O bservando el Islam, Barcelona, Paidós.

GIUMBELLI, E.

19970 cuidado dos mortos. U ma história da condenação e legitimação do E spiritismo, Rio de Janeiro, Arquivo Nacional.

LE GOFF, J.

2001 São F rancisoo de A ssis, Rio de Janeiro, Record.

LEWGOI, B.

2001

"Chico Xavier e a cultura brasileira", Revista de A ntropologia, 44(1): 63115.

MACHAD O, U.

1983 Os intelectuais e 0 espiritismo, Rio de Janeiro, Antares/ INL.

MAGGIE, Y.

1992 Medo de feitico: relagọes entre a magia e 0 poder no Brasil, Rio de Janeiro, Arquivo Nacional.

MAGNANI, J. G.

1999 Mystica Urbe. Um estudo antropológico sobre 0 circuito neo-esotérico na metrópole, São Paulo, Studio Nobel.

MARIZ, C. \& MACHAD O, M. D .

1994 "Sincretismo e trânsito religioso: comparando carismáticos e pentecostais", Comunicayões do ISE R, n. 45: 24-34.

NEGRÃO, L.

1997

"Refazendo antigas e urdindo novas tramas: trajetórias do sagrado", Re ligião e Sociedade, v. 18(2): 63-74.

ORTIZ, R.

1991 [1978] A morte branca do feitioeiro negro, São Paulo, Brasiliense. 
Sandra Jacqueline Stoll. Religião, ciênCia ou auto-ajuda?

PRANDI, R.

1996 H erdeiras do axé, São Paulo, Hucitec.

RODRIGUES, A. M. \& MUEL-D REYFUS, F.

1987 "Reencarnações. Notas de pesquisa sobre uma seita espírita em Brasília", Revista Brasileira deC iências Sociais, 31: 102-121.

SAHLINS, M.

1990 Ilhas de história, Rio de Janeiro, Jorge Zahar.

SANCHIS, P.

$1994 a$

"Para não dizer que não falei de sincretismo", C omunicaọes do ISE R, n. 45: $4-11$.

1994b “O repto pentecostal à cultura católico-brasileira”, Revista deA ntropologia, 37: 145-181.

SOARES, L.E.

1979

"O autor e seu duplo: a psicografia e as proezas do simulacro", Religião e Sociedade, v. 4: 121-140.

STOLL, S.J.

1999 E ntredois mundos: o espiritismo da França eno Brasil, São Paulo, tese, Universidade de São Paulo.

TIMPONI, M.

1978 [1959] A psicografia ante os tribunais, Rio de Janeiro, Federação Espírita Brasileira.

\section{Obras espíritas}

BACELLI, C.

1987 Chioo X avier - mediunidade evida, São Paulo, Instituto de Divulgação Editora André Luiz.

BARBOSA, E.

1992 [1967] N o mundo de C hico X avier, São Paulo, IDE. 
COSTA E SILVA, L.

1995 [1977] N osso amigo C hico X avier, São Paulo, EME.

GAMA, R.

1995 [1955] L indos casos de Chio X avier, São Paulo, LAKE.

MACHAD O , U.

1992 [1984] C hioo X avier - uma vida deamor, São Paulo, ID E.

NOBRE, M. R. S.

1996 Li iões de sabedoria. Chico X avier nos 22 anos da Folha E spírita, São Paulo, EditoraJornalística Fé.

RANIERI, R. A.

1988 Recordag̣oes de Chico X avier, São Paulo, Fraternidade.

SCHUBERT, S.

1991 Testemunhos de Chico X avier, Rio de Janeiro, Federação Espírita Brasileira.

1995 A s vidas de Chico $\mathrm{X}$ avier, Rio de Janeiro, Rocco.

SOUTO MAIOR, M.

1995 A s vidas de Chio X avier, Rio de Janeiro, Rocco.

TAVARES, C.

1991 [1967] Trinta anos com Chico X avier, São Paulo, IDE.

XAVIER, F. C.

1932

"Palavras Minhas", in Parnaso de além-túmulo, Rio de Janeiro, Federação Espírita Brasileira.

1938 "Explicando", in E mmanuel, Rio de Janeiro, Federação Espírita Brasileira.

WORM, F.

1996

A ponte: diálogos œm Chio X avier, São Paulo, Lake. 


\begin{abstract}
This article aims to examine some recent characteristics of Spiritism in Brazil. It points out, in first place, the omission of the bibliography on the theme regarding to the historical relations established between Spiritism and Catholicism. Next, analyzing the contemporaneous status, it presents new relations Spiritism has established with other religions and science as a strategy of innovation. Based on case-studies, this article presents three personalities - Chico X avier, Waldo Vieira and Luiz Antonio G asparetto - who synthesize, through their life-stories, some of the current forms of expressing or contesting spiritist "tradition".
\end{abstract}

KEY-WORDS: Spinitism, saintliness, Chico Xavier, Waldo Vieira, Luiz Gasparetto.

Recebido em setembro de 2002. 